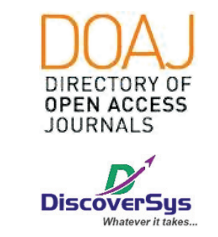

Published by DiscoverSys

\section{Sore throat pada siswa-siswi perokok dan non-perokok SMA Kota Denpasar tahun 2017}

\author{
Tommy Sutanto, ${ }^{1 *}$ Putu Aryani, ${ }^{2}$ Anak Agung Sagung Sawitri ${ }^{3}$
}

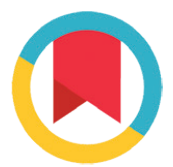

CrossMark

\title{
ABSTRACT
}

Background: Sore throat is a symptom that occurs due to the inflammation process that often disrupts everyday activities and decreases the quality of life of the patient. Smoking cigarette is one of the causes of a sore throat. Prevalence of smokers in Indonesia, especially in adolescents has reached $45 \%$.

Aim: This study aimed to find the prevalence of sore throat as well as its tendency on smokers and non-smokers in high school students in Denpasar City and the characteristics of sore throat and smoking behavior. Method: This is a descriptive study with a cross sectional research design. The samples of this study are students of SMA PGRI 1 Denpasar. The data in this study is primary data, gathered from questionnaires. Result: Of the 63 samples included in the study, it was found that the prevalence of active smokers among high school students in Denpasar city reached $27 \%(95 \% \mathrm{Cl}: 16.6-39.7)$ with a higher proportion of men. The sore throat tends to occur more on active smokers with a proportion of $76.5 \%$ (95\%(l: 50.1-93.2) than non-smokers with a proportion of $63 \%$ (95\% Cl: 47.5-76.8). Smoking behavior was found to have started, mostly, for 12 months with everyday consumption as the majority. The number of cigarettes smoked could reach 16 cigarettes a day.

Conclusion: Sore throat tends to occur more on smokers than nonsmokers even though the difference is not a lot. The results of this study are expected to be used to educate adolescents about the harmful effect of smoking cigarette on health, considered on making policies around the consumption of cigarette in students and to be a foundation for further research to find the relationship between smoking behavior and sore throat.

Keywords: Sore throat, smoking, adolescents

Cite This Article: Sutanto, T., Aryani, P., Sawitri, A.A.S. 2020. Sore throat pada siswa-siswi perokok dan non-perokok SMA Kota Denpasar tahun 2017. Intisari Sains Medis 11(1):263-267. D0I: 10.15562/ism.v1111.218

\section{ABSTRAK}

Sore throat merupakan gejala yang terjadi akibat proses inflamasi yang sering kali mengganggu kegiatan sehari-hari dan menurunkan kualitas hidup penderita. Merokok merupakan salah satu penyebab dari munculnya gejala ini. Prevalensi perilaku merokok di Indonesia, khususnya golongan remaja sudah mencapai $45.0 \%$.

Tujuan: Untuk mencari prevalensi sore throat serta kecenderungan nya pada siswa-siswi perokok dan non-perokok SMA kota Denpasar serta mendapatkan karakteristik dari sore throat dan perilaku merokok. Metode: Penelitian ini bersifat deskriptif dengan rancangan penelitian potong lintang. Sampel pada penelitian ini adalah siswa-siswi SMA PGRI 1 Denpasar. Data penelitian bersifat data primer dengan menggunakan kuesioner angket yang diisi sendiri oleh sampel.

'Program Studi Pendidikan Dokter, Fakultas Kedokteran, Universitas Udayana,

${ }^{2}$ Departemen IImu Kesehatan Masyarakat dan Kedokteran Pencegahan, Fakultas Kedokteran Universitas Udayana

${ }^{*}$ Correspondence to: Tommy Sutanto, Program Studi Pendidikan Dokter, Fakultas Kedokteran, Universitas Udayana sutanto.tommy@gmail.com

Diterima: 04-08-2018

Disetujui: 08-08-2018

Diterbitkan: 27-03-2020
Hasil: Dari 63 sampel yang diikutsertakan dalam peneltiian didapatkan prevalensi perokok aktif SMA kota Denpasar sebesar 27\% (95\%Cl:
16,6-39,7) dengan proporsi pria yang lebih banyak. Sore throat lebih cenderung terjadi pada perokok aktif yaitu 76,5\% (95\%Cl: 50,1-93,2) dibandingkan non-perokok yaitu $63 \%$ (95\% Cl: 47,5-76,8). Perilaku merokok ditemukan paling banyak sudah dilakukan semenjak 12 bulan terakhir dengan frekuensi konsumsi tersering adalah setiap hari dengan jumlah batang rokok yang dikonsumsi dapat mencapai 16 batang perhari. Simpulan: Sore throat memiliki kecenderungan untuk lebih banyak terjadi pada perokok dibandingkan non-perokok walaupun tidak jauh berbeda. Hasil penelitian ini diharapkan dapat diterapkan untuk mengedukasi pelajar remaja tentang pengaruh rokok terhadap kesehatan, digunakan untuk pertimbangan pembuatan peraturan seputar konsumsi rokok di kalangan pelajar dan menjadi dasar untuk penelitian lebih lanjut untuk menemukan hubungan antara perilaku merokok dengan sore throat.
Kata kunci: Sore throat, merokok, remaja

Cite Pasal Ini: Sutanto, T., Aryani, P., Sawitri, A.A.S. 2020. Sore throat pada siswa-siswi perokok dan non-perokok SMA Kota Denpasar tahun 2017. Intisari Sains Medis 11(1): 263-267. D0I: 10.15562/ism.v11i1.218

\section{PENDAHULUAN}

Salah satu penyakit yang cukup banyak ditemukan dan membuat pasien mengunjungi primary care adalah sore throat. ${ }^{1}$ Sore throat, atau sakit tenggorokan, merupakan suatu kejadian di mana terjadi proses inflamasi pada bagian faring, tonsil, ataupun nasofaring. ${ }^{2}$ Data prevalensi dan insiden sore throat tidak banyak karena penderita sore throat jarang mengunjungi dokter dan menunggu hingga sembuh 
sendiri sehingga sering disebut self-limiting. ${ }^{3}$ Angka kunjungan pasien akibat sore throat ke dokter keluarga di Inggris pada tahun 2007 adalah 4\%. ${ }^{4}$ Pada Negara maju seperti Inggris, 9 dari 100 pasien yang mengunjungi dokter layanan primer mengeluh sore throat. Insiden sore throat pada tahun 2013 Negara Inggris adalah 60 dari $100.000 .{ }^{1}$ Selain itu, didapatkan juga data yang menunjukan bahwa sore throat dapat menyebabkan impairment dalam aktifikas sehari-hari seperti berbicara, menelan, makan, tidur, kerja dan berkonsentrasi. ${ }^{3}$ Merokok merupakan salah satu penyebab dari timbulnya sore throat. Pada penelitian yang dilakukan oleh Paul Litter et al, ditemukan 2.942 dari 13.934 partisipan yang mengalami gejala sore throat merupakan perokok. ${ }^{5}$ Terdapat juga hubungan antara jumlah rokok dengan durasi sore throat yang memanjang. ${ }^{6}$

Menurut artikel liputan6 tanggal 5 Desember 2014, dikatakan $45 \%$ anak remaja Indonesia berumur 14-19 tahun sudah menjadi perokok aktif. Selain itu Indonesia merupakan negara dengan jumlah perokok remaja tertinggi di dunia menurut Global Youth Tobacco Survey. ${ }^{7}$ Sedangkan WHO menunjukan prevalensi perokok di Indonesia tahun 2012 untuk umur 15 tahun keatas mencapai $67 \%$. Proporsi perokok pria juga ditemukan jauh lebih tinggi dari wanita dengan perbandingan $67,0 \%: 2,1 \%{ }^{8}$

Peneltian tahun 2013 yang dilakukan oleh Kementerian Kesehatan RI menunjukkan bahwa rata-rata perokok aktif yang berusia $>10$ tahun merokok sekitar 12,3 batang rokok atau hampir setara dengan satu bungkus rokok setiap harinya. Penemuan lain yang didapatkan adalah peningkatan proporsi perokok usia $>15$ tahun terus meningkat yang proporsinya 34,2\% di tahun 2007 menjadi $36,3 \%$ di tahun 2013. Untuk daerah Bali, ditemukan proporsi perokok usia $>10$ tahun mencapai $18 \%$ untuk perokok harian dan $4,4 \%$ untuk perokok kadang-kadang. Riset yang dilakukan juga menunjukkan bahwa proporsi tertinggi perokok adalah populasi tamatan SMA yang mencapai $28,7 \% .{ }^{9}$ Banyaknya perokok di Indonesia tentu menjadi masalah yang perlu diamati. Merokok dapat menimbulkan masalah kesehatan, khususnya pada turunnya fungsi paru-paru dan meningkatnya masalah saluran pernafasan lainnya. ${ }^{6}$

Tingginya jumlah perokok Indonesia usia remaja menjadi suatu masalah yang perlu ditangani dan ditelaah. Salah satu konsekuensi akibat merokok adalah terjadinya sore throat. Perilaku merokok yang berkelanjutan juga dapat menimbulkan risiko kesehatan yang lebih berbahaya seperti kanker paru, hipertensi, serta impoten. Tidak hanya itu, rokok juga dapat menyebabkan tubuh lebih rentan terinfeksi bakteri dan mengalami infeksi pada saluran pernafasan atas. ${ }^{8}$ Sore throat merupakan hal yang mempengaruhi kualitas hidup, terutama siswa-siswi pelajar sekolah karena dapat mengganggu konsentrasi belajar, gangguan berkomunikasi, dan menyebabkan sulit tidur. ${ }^{3}$ Namun nyatanya masih sedikit data yang menunjukan prevalensi sore throat pada siswa-siswi remaja perokok SMA di kota Denpasar. Dari pengamatan dan survey, ditemukan siswa-siswa SMA yang merokok, terutama siswa dari SMA PGRI 1 Denpasar yang berlokasi di jalan Waturenggong. SMA ini juga dipilih karena lokasinya yang dekat dengan kampus Fakultas Kedokteran Universitas Udayana sehingga penelitian dapat menjadi lebih terjangkau.

\section{METODE}

Penelitian ini adalah suatu penelitian deskriptif dengan pendekatan cross sectional yang dilakukan di SMA PGRI 1 Denpasar tahun ajaran 2017. Pengukuran jumlah sampel dilakukan dengan rumus sampel tunggal dan ditemukan jumlah yang dibutuhkan sebanyak 80 sampel. Kriteria inklusi pada penelitian ini adalah subjek merupakan siswa-siswi aktif kelas X-XII dan diperkenankan serta setuju untuk berpartisipasi dalam penelitian. Kriteria eksklusi peneltiian ini adalah subjek yang tidak hadir saat pengumpulan data.

Pengumpulan data akan dilakukan dengan menggunakan instrumen angket (Self-Administered Questionnaire) yang diisi langsung oleh responden secara anonim. Data dari hasil penelitian diproses dan ditabulasi menggunakan aplikasi program SPSS. Analisa data yang dilakukan berupa tabulasi silang proporsi untuk mencari kecenderungan data.

\section{HASIL}

Jumlah siswa-siswi tahun ajaran 2017 yang terdaftar di SMA PGRI 1 Denpasar berjumlah 90 pada saat pengumpulan data dilakukan bulan Oktober 2017. Sebanyak 27 siswa-siswi tidak hadir saat waktu pengumpulan data sehingga jumlah sampel hanya 63.

Tabel 1 menunjukan jumlah sampel yang didapatkan pada pengumpulan data berjumlah 63 sampel. Diantaranya 50,8\% adalah wanita dan $49,2 \%$ adalah pria. Usia responden bervariasi dari umur 15 - 18 tahun di mana usia 17 tahun merupakan usia terbanyak dengan persentase $31,7 \%$. Sampel diambil dari SMA dengan kelas XII merupakan kelas terbanyak yaitu $44,4 \%$ dari seluruh sampel.

Prevalensi sore throat pada siswa-siswi perokok dan non-perokok SMA PGRI 1 Denpasar didapatkan $66,7 \%(n=42)$. Gejala sore throat yang lebih rinci bisa dilihat di tabel 2. Responden yang mengalami gejala sore throat mengambil langkah tindakan intervensi medis lebih banyak dalam 
Tabel 1 Karakteristik responden

\begin{tabular}{lcc}
\hline Variabel & Jumlah $(\mathbf{n}=\mathbf{6 3})$ & Persentase (\%) \\
\hline Jenis Kelamin & 31 & 49,2 \\
$\quad$ Pria & 32 & 50,8 \\
Wanita & & \\
Usia & 10 & 15,9 \\
15 Tahun & 18 & 28,6 \\
16 Tahun & 20 & 31,7 \\
17 Tahun & 15 & 23,8 \\
18 Tahun & & \\
Kelas & 19 & 30,2 \\
X & 16 & 25,4 \\
XI & 28 & 44,4 \\
XII & & \\
\hline
\end{tabular}

Tabel 2 Gejala dan tindakan medis pada sore throat

\begin{tabular}{lcccc}
\hline & \multicolumn{5}{c}{ Gejala (n=63) } \\
\cline { 2 - 5 } & \multicolumn{3}{c}{ Ya } & \multicolumn{3}{c}{ Tidak } \\
\cline { 2 - 5 } & $\mathbf{n}$ & \% & $\mathbf{n}$ & \% \\
\hline Nama Gejala & & & & \\
$\quad$ Batuk & 36 & 57.1 & 27 & 42.9 \\
$\quad$ Rasa sakit di tenggorokan & 27 & 42.9 & 36 & 57.1 \\
Sensasi panas di tenggorokan & 13 & 20.6 & 50 & 79.4 \\
Demam & 29 & 46.0 & 34 & 54.0 \\
$\quad$ Pembengkakan Leher & 1 & 1.6 & 62 & 98.4 \\
Tindakan Medis & & & & \\
$\quad$ Fasilitas Kesehatan & 25 & 39.7 & 38 & 60.3 \\
Medikasi Obat & 33 & 52.4 & 30 & 47.6 \\
\hline
\end{tabular}

\section{Tabel 3 Karakteristik perilaku merokok}

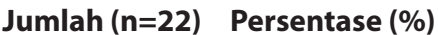

\begin{tabular}{lcc}
\hline Lama Konsumsi Rokok (bulan) & & \\
$1-28$ & 18 & 81,8 \\
$29-56$ & 3 & 13,6 \\
$\quad>56$ & 1 & 4,6 \\
$\quad$ Frekuensi Merokok Dalam 1 Minggu (hari) & 4 & \\
$\quad<3$ & 18 & 18,2 \\
$\geq 3$ & & 81,8 \\
Jumlah Batang Rokok Dalam 1 Hari & 11 & \\
$<5$ & 9 & 50,0 \\
$5-15$ & 2 & 40,9 \\
$\geq 15$ & & 9,1
\end{tabular}

rupa pengobatan sendiri dengan meminum obat sebanyak $52,4 \%$ dibandingkan dengan yang pergi mencari layanan fasililitas kesehatan sebanyak $39,7 \%$.
Sore throat merupakan keluhan yang kerap kali ditemukan dalam praktek dokter namun lebih bersifat self-limiting disease dan penderita baru mencari pertolongan medis apabila sakitnya memburuk. Apabila sore throat dibiarkan memburuk, maka dapat terjadi penurunan kualitas hidup dan mengganggu kegiatan sehari-hari penderita. ${ }^{3}$ Hal ini terlihat pada data di mana hanya sekitar $39,7 \%$ penderita sore throat yang mencari pertolongan medis ke fasilitas kesehatan. Di negara Inggris, hanya $4 \%$ kunjungan ke fasilitas kesehatan disebabkan oleh sore throat. Adapun alasan hal ini bisa berupa karena penyakit ini yang self-limiting ataupun penderita sudah melakukan self-medication di rumah dengan obat.

Karakteristik perilaku merokok responden ditemukan sejumlah $22(34,9 \%)$ siswa-siswi SMA PGRI 1 memiliki riwayat pernah merokok dan sejumlah 17 (27\%) masih merokok aktif selama 6 bulan terakhir. Lebih dari setengah sampel tidak pernah merokok walaupun sejumlah 32 (50,8\%) sampel memiliki kerabat yang merokok di rumah. Tabel 3 menunjukan data yang lebih rinci seputar perilaku merokok responden.

Data karakteristik merokok yang didapatkan pada SMA PGRI 1 berbeda sedikit dengan data penelitian yang dilakukan di SMA lain. Prevalensi perokok di Denpasar lebih tinggi dibandingkan dengan kota Bogor yang hanya 18,5\%. ${ }^{9}$ Apabila dibandingkan dengan data lain, prevalensi perokok di penelitian ini (27\%) lebih rendah dibandingkan data yang didapatkan oleh Global Youth Tobacco Survey yang menyatakan $45 \%$ anak remaja Indonesia berusia 14-19 tahun adalah perokok aktif. ${ }^{10}$ Perbedaan serupa juga ditemukan pada data WHO tahun 2012 yang menunjukan 67\% populasi Indonesia berusia $>15$ tahun merupakan perokok aktif. ${ }^{11}$ Data riskesdas tahun 2013 menunjukan perokok aktif harian di Bali hanya $18 \%$ dan pada penelitian ini ditemukan hasil yang lebih tinggi. ${ }^{7}$ Perbedaan ini mungkin terjadi karena terdapat perbedaan lokasi sampling dan juga jumlah sampel yang digunakan pada penelitian. Peraturan dan larangan penjualan dan konsumsi rokok juga mungkin berbeda di setiap lokasi. Pada lokasi penelitian SMA PGRI 1 Denpasar, terdapat larangan merokok di area sekolah, hal ini mungkin menyebabkan prevalensi perokok lebih rendah dibanding dengan lokasi lain. Selain itu sampel yang tidak hadir saat pengumpulan data juga dapat merubah hasil penelitian. Perbedaan juga mungkin terjadi dikarenakan waktu penelitian yang berbeda sehingga menghasilkan data yang berbeda.

Pada SMA PGRI 1 Denpasar, ditemukan 50\% sampel merokok $<5$ batang perhari sedangkan SMA Negeri 1 Semarapura hanya 33,3\%. Perbedaan juga terlihat untuk kategori 5-15 batang perhari 
Tabel 4 Tabulasi silang karakteristik responden - perilaku meroko

\begin{tabular}{llccc}
\hline & & \multicolumn{2}{c}{ Aktif Merokok dalam 6 bulan } & \\
\cline { 3 - 4 } & & Ya & Tidak & Total \\
\hline \multirow{2}{*}{ Jenis Kelamin } & Pria & $16(51,6 \%)$ & $15(48,4 \%)$ & $31(100,0 \%)$ \\
& Wanita & $1(3,1 \%)$ & $31(96,9 \%)$ & $32(100,0 \%)$ \\
\multirow{3}{*}{ Usia } & 15 Tahun & $1(10,0 \%)$ & $9(90,0 \%)$ & $10(100,0 \%)$ \\
& 16 Tahun & $6(33,3 \%)$ & $12(66,7 \%)$ & $18(100,0 \%)$ \\
& 17 Tahun & $2(10,0 \%)$ & $18(90,0 \%)$ & $20(100,0 \%)$ \\
& 18 Tahun & $8(53,3 \%)$ & $7(46,7 \%)$ & $15(100,0 \%)$ \\
\hline
\end{tabular}

Tabel 5 Tabulasi silang karakteristik responden - sore throat

\begin{tabular}{llccc}
\hline & & \multicolumn{2}{c}{ Sore Throat } & \multirow{2}{*}{ Total } \\
\cline { 3 - 4 } & & Ya & Tidak & \\
\cline { 3 - 4 } Jenis Kelamin & Pria & $22(71,0 \%)$ & $9(29,0 \%)$ & $31(100,0 \%)$ \\
& Wanita & $20(62,5 \%)$ & $12(37,5 \%)$ & $32(100,0 \%)$ \\
Usia & 15 Tahun & $5(50,0 \%)$ & $5(50,0 \%)$ & $10(100,0 \%)$ \\
& 16 Tahun & $11(61,1 \%)$ & $7(38,9 \%)$ & $18(100,0 \%)$ \\
& 17 Tahun & $14(70,0 \%)$ & $6(30,0 \%)$ & $20(100,0 \%)$ \\
Pernah Merokok & Ya Tahun & $12(80,0 \%)$ & $3(20,0 \%)$ & $15(100,0 \%)$ \\
& Tidak & $18(81,8 \%)$ & $4(18,2 \%)$ & $22(100,0 \%)$ \\
Aktif Merokok & Ya & $24(58,5 \%)$ & $17(41,5 \%)$ & $41(100,0 \%)$ \\
dalam 6 bulan & Tidak & $29(63 \%)$ & $17(37 \%)$ & $46(100,0 \%)$ \\
\hline
\end{tabular}

dan $>15$ batang perhari di mana SMA PGRI 1 Denpasar didapatkan $40,9 \%$ dan $9,1 \%$ dan SMA Negeri 1 Semarapura didapatkan $58,7 \%$ dan $7,9 \% .{ }^{12}$ Di sini terlihat tren merokok yang berbeda di mana SMA PGRI 1 Denpasar lebih cenderung merokok $<5$ batang perhari. Tren merokok pada penelitian ini lebih serupa dengan penelitian yang dilakukan di kota Bogor di mana kategori $<5$ batang perhari merupakan mayoritas dengan persentase di Bogor mencapai 54,1\%.9 Pada penelitian Kementerian Kesehatan RI didapatkan rata-rata konsumsi perokok usia $>10$ tahun adalah 12,3 batang perhari, namun pada penelitian ini rerata yang didapatkan adalah 6 batang perhari. ${ }^{7}$ Walaupun terdapat perbedaan tersebut, perlu diingat bahwa sebaran data yang didapatkan pada penelitian bersifat tidak normal sehingga tidaklah tepat untuk menyimpulkan data denganmelihat reratanya.

Untuk frekuensi merokok, Perokok harian (7 hari seminggu) di SMA PGRI 1 merupakan mayoritas, namun di kota Bogor didapatkan merokok 1-14 hari dalam sebulan sebagai mayoritas. Lama konsumsi rokok juga didapatkan tren yang sama di kota Bogor dengan kategori $<28$ bulan sebagai mayoritas. ${ }^{9}$

Tabel 4 menunjukan kecenderungan perilaku merokok berdasarkan jenis kelamin serta usia responden. Dari seluruh sampel ditemukan prevalensi perokok di SMA PGRI 1 Denpasar sebesar 27\% (95\% CI: 16,6 - 39,7) atau sebanyak 17 siswasiswi. Diantara angka tersebut, ditemukan kecenderungan perilaku merokok dengan jenis kelamin, yaitu perilaku merokok lebih cenderung terjadi di pria dibandingkan pada wanita. Dari faktor usia, ditemukan perokok paling banyak di usia 18 tahun. Responden berusia 15 tahun dan 17 tahun terlihat paling cenderung untuk tidak merokok dibandingkan usia 16 dan 18 tahun.

Riset nasional yang dilakukan oleh Kementerian Kesehatan RI tahun 2013 menunjukan bahwa $36,3 \%$ penduduk Indonesia berusia $>15$ tahun merupakan perokok aktif. ${ }^{7}$ Data yang didapatkan dari penelitian menunjukan prevalensi perokok di kota Denpasar lebih rendah dari prevalensi nasional. Perbedaan ini bisa terjadi karena jumlah sampel yang diambil untuk riset nasional jauh lebih banyak dibandingkan penelitian ini.

Meninjau dari segi karakteristik jenis kelamin, Riskesdas 2013 menunjukan proporsi perokok segala usia pada pria $67.0 \%$ sedangkan wanita $2.1 \% .^{7}$ Penelitian ini menunjukan tren yang sama di mana proporsi perokok pada pria lebih tinggi dibandingkan wanita dengan perbedaan sedikit dimana di Denpasar proporsi perokok pria adalah 51,6\% (95\% CI: 33,1 - 69,8) dan wanita $3,1 \%(1,0-16,2)$.

Tabel 5 menunjukan kecenderungan sore throat dengan faktor jenis kelamin, usia, serta status merokok responden. Keluhan sore throat cenderung dialami lebih banyak oleh pria dibandingkan wanita walaupun tidak berbeda banyak. Dari faktor usia, tidak terlalu banyak ditemukan perbedaan namun terlihat lebih banyak proporsi sore throat pada usia 18 tahun dan 17 tahun. Pada responden yang memiliki riwayat merokok, didapatkan $81,8 \%$ (95\% CI: 59,7 - 94,8) dari responden pernah mengalami sore throat dalam 6 bulan terakhir dibandingkan dengan responden yang tidak memiliki riwayat merokok dengan hasil 58,5\% (95\% CI: 42,1 - 73,7). Data menunjukan bahwa sore throat cenderung terjadi lebih banyak di kalangan siswa-siswi yang memiliki riwayat merokok. Pada perokok aktif, persentase sore throat adalah 76,5\% (95\% CI: 50,1 $93,2)$ dibandingkan dengan non-aktif $63 \%$ (95\% CI: 47,5 - 76,8). Dari data ini terlihat kecenderungan yang sama, yaitu siswa-siswi dengan riwayat merokok memiliki kecenderungan untuk mengalami sore throat yang lebih tinggi.

Penelitian di Amerika Serikat yang dilakukan terhadap mahasiswa perkuliahan menunjukkan proporsi sore throat pada perokok lebih tinggi dibandingkan non-perokok dengan angka 73,7\% dibandingkan 62,5\%. ${ }^{6}$ Data tersebut menunjukkan kecenderungan yang sama dengan penelitian ini, 
yaitu perokok lebih cenderung mengalami sore throat dibandingkan non-perokok 76,5\% (95\% CI: 50,1-93,2) dibanding 63\% (95\% CI: 47,5 - 76,8). Korelasi antara perilaku merokok dengan keluhan sore throat sudah ditemukan pada penelitian An, et al. (2009) di mana perokok lebih berpeluang 1,68 kali mengalami sore throat dibandingkan dengan non-perokok. ${ }^{6}$ Pada penelitian ini tidak dilakukan analisis korelasi, namun dengan data deskriptif terlihat kecenderungan yang mendukung data korelasi tersebut.

\section{SIMPULAN}

Prevalensi perokok aktif pada sekolah menengah atas di daerah Denpasar ditemukan sebesar 27\% (95\% CI: 16,6 - 39,7), dengan perbandingan angka pada pria dan wanita yang sangat besar. Perbandingan proporsi sore throat pada perokok dan bukan perokok tidak terlalu tinggi $(76,5 \%$ vs $63 \%)$. Siswa-siswi perokok telah merokok selama 1 - 84 bulan di mana yang paling banyak adalah 12 bulan. Perokok dapat mengonsumsi sampai 16 batang rokok setiap hari dengan frekuensi yang tersering adalah 7 hari dalam seminggu. Sore throat yang ditemukan beragam namun gejala batuk merupakan keluhan terbanyak, diikuti oleh demam, rasa sakit di tenggorokan, serta sensasi panas di tenggorokan. Pembengkakan leher merupakan gejala paling sedikit pada sampel. Penderita sore throat lebih banyak melakukan intervensi medis berupa self-medicating dengan obat dibandingkan pergi ke fasilitas kesehatan.

\section{KETERBATASAN PENELITIAN}

Penelitian ini menggunakan kuesioner yang dibuat oleh peneliti namun belum dilakukan validasi, sehingga belum memenuhi standar validitas dan realibilitas kuesioner. Selain hal ini, jumlah sampel yang didapatkan pada akhir penelitian berjumlah 63 dari estimasi sampel hasil perhitungan. Berkurangnya sampel dapat mempengaruhi akurasi dan kualitas hasil penelitian. Dari aspek representatif pada populasi, berkurangnya sampel merubah gambaran pada populasi. Sampel yang tidak hadir saat pengumpulan data juga mungkin memiliki karakteristik yang berbeda dengan sampel yang didapatkan, sehingga mungkin dapat memberikan hasil yang berbeda dari penelitian ini.

\section{KONFLIK KEPENTINGAN}

Tidak ada konflik kepentingan dalam pengerjaan naskah penelitian ini.

\section{DAFTAR PUSTAKA}

1. Cook J, Hayward G, Thompson M, Hay AD, Moore M, Little P, dkk. Oral corticosteroid use for clinical and cost-effective symptom relief of sore throat: study protocol for a randomized controlled trial. Trials. 2014;15:365.

2. Pelucchi C, Grigoryan L, Galeone C, Esposito S, Huovinen P, Little P, dkk. Guideline for the management of acute sore throat: ESCMID Sore Throat Guideline Group C. Pelucchi dkk. Guideline for management of acute sore throat. Clinical Microbioly Infection. 2012;18:1-28.

3. Addey D, Shephard A. Incidence, causes, severity and treatment of throat discomfort: A four-region online questionnaire survey. BMC Ear, Nose and Throat Disorders. 2012;12(1):1

4. Worall G. Acute sore throat. Canadian Famoly physician. 2007;53:1961-2.

5. Little P, Stuart B, Richard Hobbs FD, Butler CC, Hay AD, Campbell J, dkk. Predictors of suppurative complications for acute sore throat in primary care: Prospective clinical cohort study. BMJ. 2013;347(November):1-14.

6. An LC, Berg CJ, Klatt CM, Perry CL, Thomas JL, Luo X, dkk. Symptoms of cough and shortness of breath among occasional young adult smokers. Nicotine Tobacco Research. 2009;11(2):126-33.

7. WHO. Global Youth Tobacco Survey (GYTS): Indonesia report 2014. WHO-Searo; 2015. 24 p.

8. WHO. WHO Report on the Global Tobacco Epidemic, 2013 Country profile; 20131-8.

9. Badan Penelitian dan Pengembangan Kesehatan. Riset Kesehatan Dasar (RISKESDAS) 2013. Laporan Nasional 2013; 2013. 1-384.

10. Bagaitkar J, Demuth DR, Scott DA. Tobacco use increases susceptibility to bacterial infection. Tobacco-Induced Diseases. 2008;4(1):12.

11. Pramintari RD, Hastuti D, Djamaludin mohammad D. Pengaruh Gaya Pengasuhan Dan Teman Sebaya Terhadap Perilaku Konsumsi Rokok Siswa SMA Di Kota Bogor. Jurnal Soul. 2014;7(2):22-34.

12. Sanjiwani NLPY, Wulan IGAP. Pola Asuh Permisif Ibu dan Perilaku Merokok Pada Remaja Laki-Laki di Sma Negeri 1 Semarapura Budisetyani. Jurnal Psikologi Udayana. 2014;1(2):344-52.

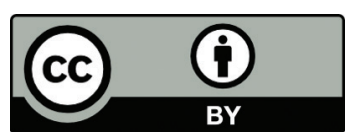

This work is licensed under a Creative Commons Attribution 